\title{
FINANCIAL AND ECONOMIC BASES OF THE FUNCTIONING OF STATE EXECUTIVE BODIES: PAST, PRESENT AND PROSPECTS OF IMPROVEMENT
}

\author{
Oleksandr Mykolenko', Iryna Lychenko², Olena Klymiuk
}

\begin{abstract}
The aim of the article is to analyse legal regulations and perspectives available in the specialized literature concerning financial and economic bases of the functioning of state executive bodies, which should be strengthened and formed according to one of the areas of administrative reform in Ukraine. The subject of the study is financial and economic bases of the functioning of state executive bodies: past, present, and prospects of improvement. Methodology. The study is based on the use of general scientific and special-scientific methods and techniques of scientific knowledge. The historical and legal method enabled to analyse the legal regulations of administrative and financial law on past, present, and prospects of improvement of financial and economic bases of the functioning of state executive bodies. The comparative legal method was used to improve the system of executive bodies and their authorities' exercise. The system-structural method enabled to consider and identify the most negative effects of the insufficient financing of executive branch activities and the exercise of their authorities. The methods of grouping and classifying were the basis for the author's approach to the identification of forms of financing state executive bodies. The technical legal method enabled to interrogate the state of affairs in financial and economic bases of the functioning of state executive bodies. The results of the study enabled to highlight the drivers of the improvement of forms of financing state executive bodies. Practical implications. In the study, scientific sources and legal regulations of administrative and financial law on past, present, and prospects of improvement of financial and economic bases of the functioning of state executive bodies are interrogated. The article highlights that strengthening and forming new financial and economic bases of the functioning of state executive bodies have been provided for by one of the areas of the Concepts of Administrative Reform, which nowadays is implemented both at the legislative and law enforcement levels. It was concluded that the formation of new financial and economic bases of the functioning of state executive bodies failed. There is only modelling of certain forms of financing of state executive bodies, familiar to the history of the origin and development of these bodies. Therefore, financial and economic bases of the functioning of state executive bodies should be interrogated by representatives of both administrative and financial law not only from a historical perspective or from a modern perspective but also with a view to the future. Relevance/originality. The original author's approach to the definition of financial and economic bases of the functioning of state executive bodies is the basis for developing the most promising areas of improvement of domestic legislation in this sphere.
\end{abstract}

Key words: administrative reform areas, state executive bodies, state budget, financial and economic bases of functioning of state executive bodies.

JEL Classification: K23, H72

\section{Introduction}

Ukraine is undergoing significant changes in all spheres of public life, mainly due to the transition from the post-Soviet system of state administration (command-administrative system) to the system of public administration, effectively manifested in democratic countries of the world. Ukraine is a democratic, social, and legal state; and human rights, freedoms, and their guarantees determine the content and targeting of public activities. However, in practice, these provisions of the Constitution of Ukraine cannot be implemented without changes in both the system of public administration and the tools used by public administrators to exercise their powers. To confirm acknowledgement of Ukraine's status as a legal democratic state, the state, represented by its bodies,

\footnotetext{
Corresponding author:

${ }^{1}$ I.I. Mechnikov Odessa National University, Ukraine.

${ }^{2}$ Lviv Polytechnic National University, Ukraine.

${ }^{3}$ State Higher Educational Institution "Vadym Hetman Kyiv National University”, Ukraine.
} 
should be responsible for asserting and ensuring human and civil rights and freedoms. This cannot be achieved without strengthening the financial and economic bases of the functioning of state executive bodies.

State executive bodies have a significant influence on the development of social relations in political, socio-cultural, and economic spheres; therefore, they are an important element in the system of public authorities, regardless of checks and balances provided by national legislation in relations between the legislative, judicial, and executive bodies. Initially during the Administrative Reform implementation, and then during the optimization of the state executive branch system, the key issues under consideration are: 1) construction of an effective system of state executive bodies with clear allocation of their authorities and responsibility; 2) creation of an effective mechanism for providing state executive bodies with professional personnel; 3) creation of effective forms of work with local self-government bodies, especially with regard to financing and implementation of authorities in the respective territory; 4) strengthening and formation of new financial and economic foundations for state executive bodies functioning. For the period of Ukraine's independence, all of the above-mentioned spheres have undergone changes, ambiguously evaluated in the specialized literature. For example, administrative procedures incorporated into the legislation, the establishment of an administrative service institution, the use of an administrative contract are considered as positive changes in the legal regulation of state executive bodies' activities. The growth of corruption, sharp decline in public servants' professionalism, and efficiency reduction in the law enforcement sphere are considered as negative changes that have taken place in the activities of state executive bodies. One of the major courses of stalling the reform of the state executive bodies is the lack of necessary economic and social conditions and underestimated importance of the financial factor in the executive branch development. Due to financial, logistical support of state executive bodies, these bodies get the opportunity not only to comply with laws but also to formulate and implement state policy in certain spheres of public life.

Therefore, the financial and economic basis of state executive bodies' functioning determines their effective performance. In view of this, it is important to track the development of scientific thought and current legislation regarding the financial and economic bases of the functioning of state executive bodies in Ukraine.

To some extent, the issues of financial and economic bases of the functioning of state executive bodies were studied by D. A. Bekerska, O. A. Bukhtiiarov, O. I. Derevchuk, S. T. Kadkalenko, O. Ye. Korystin, H. A. Kravchuk, M. P. Kucheriavenko, O. P. Orliuk, P. S. Patsurkivskyi, D. P. Rotar, I. Ye. Rukolainina,
L. A. Savchenko, D. L. Chernykov, A. H. Chubenko and other domestic scientists. However, in specialized legal literature, works, which reveal the essence of financial and economic bases of the functioning of state executive bodies as one of the areas of their reformation, are rare.

Therefore, consideration of the doctrinal approaches to the financial and economic bases of the functioning of state executive bodies becomes relevant and constructs the aim of this article. For its successful achievement, the following tasks should be solved: first, to outline the key aspects of financial and economic bases of the functioning of state executive bodies; second, to analyse the perspectives available in the specialized literature in relation to financial and economic bases of the functioning of state executive bodies; third, to propose an author's original approach to the improvement of financial and economic bases of the functioning of state executive bodies.

\section{Presentation of the main material}

Initially, the Concept of Administrative Reform in Ukraine, approved by the Decree of the President of Ukraine of July 22, 1998 (The Concept of Administrative Reform in Ukraine), stated the necessity to develop and incorporate into the national legislation the new financial and economic foundations of the functioning of public administration. The key areas of such a reform were: creation of a new legal framework regulating state administration in Ukraine; formation of new institutes, organizational structures and instruments of public administration; staffing of the new public administration system; scientific and informational support of the state administration system, formation of scientific and informational monitoring of its functioning; strengthening and shaping new financial and economic foundations for public administration functioning.

Over the last twenty years, firstly, the terminology has changed in the science of administrative law (instead of the term "state management," the terms "public management" and "public administration" are used), and secondly, each of the above-mentioned areas have received the corresponding implementation both at the legislative and enforcement levels (for example, the Laws "On Central Executive Bodies," "On Administrative Services," "On Public Service," the Concept of the Development of Electronic Governance in Ukraine, etc. were adopted).

However, along with a large number of proposals for improving the system of executive bodies and the exercise of their authorities, the Concept of Administrative Reform (hereinafter - the Concept) insufficiently revealed the content of an area of administrative reform such as strengthening and shaping new financial and economic foundations of the functioning of executive bodies. 
First, the Concept noted that the cost of maintaining managerial staff (officials) would be adequate for the financial and economic conditions of the state. However, the Analysis of State and Local Budget expenditures in the first half of 2014-2017, prepared by the Financial and Economic Analysis Office of the Verkhovna Rada of Ukraine (Analiz vydatkiv derzhavnoho ta mistsevykh biudzhetiv u I pivrichchi 2014-2017), demonstrates that this provision of the Concept is ignored and not realized due to many subjective and objective reasons. For example, in comparison with January-June 2014, in JanuaryJune 2017 state budget, the share of expenditures on national functions increased from $21.7 \%$ to $28.2 \%$ due to the minimum wage increase, salaries of public servants, subsistence minimum, etc. While in 2014, the largest share was spent on social protection and social security, in 2017, it was expenditures on state functions. At the same time, it was noted that expenditures on social protection and social security decreased from $32.6 \%$ to $25.8 \%$, on education, from $10.9 \%$ to $8.6 \%$, and on health care, from $2.7 \% \%$ to $1.8 \%$. However, to advocate the current situation, the transfer of a part of financing social functions of state authorities, financing educational institutions and health care facilities to the local level is considered as an argument.

Second, in the Concept, in the part concerning its financial and economic provision, it was noted that the practice of financing the executive bodies from the socalled additional mobilized and self-sustaining funds should be ceased (The Concept of Administrative Reform in Ukraine). For example, during the course of 1998, the Cabinet of Ministers of Ukraine was empowered to take a decision on the allocation of funds for the payment of salaries, pensions, scholarships, and other social payments by mobilizing additional funds (Pro mobilizatsiiu dodatkovykh koshtiv na finansuvannia sotsialnykh vyplat). However, the key elements that characterize state expenditures are: a certain complex of basic and working capital provided for the organization, its operational and economic independence, self-responsibility for all economic transactions and concern on their results. That is, the self-supporting relations are not inherent to budget organizations, and especially to executive bodies, because they have the right to spend only general and special funds of the state budget.

The possibility for the executive bodies to create and dispose of extrabudgetary funds is mentioned in the scientific literature of the early 70 s-90s of the last century. For example, D. A. Bekerska defines "extrabudgetary funds"/own receipts as permits by the competent authorities to receive revenues from various enterprises, institutions, organizations for the execution of works, the provision of services, sales of products, sums with the right to their targeted use, as well as the sums received from interest deductions of individual departments for the execution of works of general-sector nature and centralized mechanisms (Bekerskaia, 1973).

However, Budget Code of Ukraine of 2001 prohibited the creation of extrabudgetary funds by state authorities, authorities of the Autonomous Republic of Crimea, local self-government bodies and other budget institutions (Biudzhetnyi kodeks Ukrainy). Later, Budget Code of Ukraine of 2010 reiterated this prohibition by providing for minor exceptions to the general rule concerning, first, the placement of temporarily free funds of a single treasury account and funds of foreign currency accounts of the state budget on deposits or through the purchase of government securities with the subsequent repay until the end of the current budget period (Part 8, Article 16), and second, the implementation of local budgets (Part 2, Article 78) (Biudzhetnyi kodeks Ukrainy).

Therefore, the adoption of the Budget Code of Ukraine of 2001 initiated the distinction between the terms "special budget fund" and "extra-budgetary funds." The current Budget Code of Ukraine (2011) provides for that own receipts of budgetary institutions are received in addition to the general budget funds and are included in the special budget fund, which consists of: 1) targeted budget revenues (including own receipts of budgetary institutions); 2) budget expenditures from specific defined revenues of the special budget fund (including own revenues of budgetary institutions); 3) budget crediting (repayment of loans to the budget with the definition of the target and granting of credits from the budget, carried out from specific defined revenues of the special fund of the budget); 4) financing of the special fund of the budget.

According to A. H. Chubenko, these provisions of the Code solve the problem of delineating state budget and extrabudgetary funds and fully comply with the principle of the budget system completeness (Chubenko, 2012).

Third, the Concept provided for that ministries, similar to most other central executive bodies, should be financed from the state budget, while a small group of central executive bodies (referred to in the Concept as "executive bureaus"), created to implement registration and authorization functions in relation to individuals and legal entities (a paid basis included) may have mixed financing, that is, both from the budget and own income. It was noted that in national legislation, counter-commercialization mechanisms for such executive bodies should be provided for.

According to the Law of Ukraine "On Central Executive Bodies" (Pro tsentralni orhany vykonavchoi vlady), the bodies authorized to provide administrative services are "public services." However, no special provision in the law regulates 
the financial and economic foundations of the functioning of public services as central executive bodies. Part 1 of Article 25 of the Law only states that financial and logistical support of the activities of ministries and other central executive bodies shall be from the State Budget of Ukraine, except in cases determined by law. That is, in each particular case, the legal regulation shall provide for the procedure for the creation, competence, and areas of executive body activities. For example, Article 28 of the Law of Ukraine "On Antimonopoly Committee of Ukraine" (Pro Antymonopolnyi komitet Ukrainy) provides for specificities of financing a central executive body with a special status, the Antimonopoly Committee of Ukraine. Financing of the Antimonopoly Committee of Ukraine and its territorial offices comes from the general and special funds of the state budget. The payment, charged to reimburse expenses on the examination of applications for concerted practice permit, the concentration of economic entities, etc., shall be credited to a special account of the special fund of the state budget. These incomes are not subject to withdrawal and are used for their targeted purpose to finance activities of the Antimonopoly Committee of Ukraine and its territorial offices, in particular, for the logistical maintenance, including transport, creation and development of information and analytical base, publication of printed matters of the Antimonopoly Committee of Ukraine, training, retraining, professional development and social and household support of employees of the Antimonopoly Committee of Ukraine and its territorial offices.

Financing and logistical maintenance of the National Police of Ukraine, as the central executive body, is carried out from the State Budget of Ukraine, as well as other sources not prohibited by law (Pro Natsionalnu politsiiu). For example, the Department of Police Security, as a structural unit of the National Police, today provides services for the protection of entities and protection of individuals on a commercial basis. Is this approach justified, especially in the context of the adoption of the Law of Ukraine "On Security Activity” in 2013 (Pro okhoronnu diialnist), according to which, security activities are defined as a type of economic activity of the provision of services for the protection of property and citizens?

For example, M. V. Zavalnyi criticizes this approach and argues that the provision of security services by the Security Police on a commercial basis contradicts the main functions and tasks of the National Police of Ukraine (Zavalnyi, 2018). N. A. Bulychova considers the financing of state executive bodies, including the bodies of Internal Affairs, from another perspective. According to her, the increasing need to raise funds of budget institutions' own revenues, along with the insufficient total financing from the general fund, indicates significant changes in the state of affairs in the national economy, such as unsatisfied demand for social services and other features, and determines the introduction of paid public services. In addition, the inclusion of special funds of state bodies in the budget provides an opportunity to realize both the public interests of the state itself and the interests of society (Bulycheva, 2004).

\section{Conclusions and perspectives for further research}

The analysis of scientific sources and current legislation regarding financial and economic bases of the functioning of state executive bodies enables to conclude:

1. Strengthening and creating new financial and economic bases of the functioning of state executive bodies is one of the areas of administrative reform in Ukraine, which was officially originated in 1998, but is being implemented both at the legislative and enforcement levels. Despite politicians' refusal to use the term "administrative reform" discredited by the inconsistent performance of state authorities in implementing the basic provisions of the Concept of Administrative Reform, reforming the state executive bodies on their democratization, optimization, decentralization, and financial and economic basis of functioning remains on the agenda.

2. The financial and economic basis for the functioning of state executive bodies is the subject of research in financial law, therefore, unfortunately, this aspect has not been comprehensively covered by studies of administrative law representatives, focused mainly on the problems of administrative and legal support of the executive bodies, optimization of their activities, improvement of public service, legal provision of relations between executive bodies and other entities, for example, natural and legal persons, local self-government bodies, etc. It is imperative to conduct further joint studies by representatives of administrative and financial law on financial and economic bases of the functioning of state executive bodies, not only in the historical aspect or from a modern perspective, but also with a look into the future. This is because to prevent corruption in executive bodies, the state has to increase gradually the cost of salary payments, implementation of the Concept of e-governance, logistical support for executive bodies, while the economic situation in the country does not allow the state to finance fully all areas in this sphere.

3. The formation of new financial and economic bases of the functioning of state executive bodies, provided for in the Concept of Administrative Reform, was not implemented. For now, previously existing forms of financing state executive bodies have only been modelled. 


\section{References:}

The Concept of Administrative Reform in Ukraine (The Decree of the President of Ukraine no. 810/98 of July 22, 1998). Retrieved from: http://zakon.rada.gov.ua/laws/show/810/98? find=1\&text=\%F4\%B3\%ED\%E0\%ED\#w1 1 (in Ukrainian)

Analiz vydatkiv derzhavnoho ta mistsevykh biudzhetiv u I pivrichchi 2014-2017 rr. [Analysis of expenditures of state and local budgets in the first half of 2014-2017]. Retrieved from: https://feao.org.ua/wp-content/uploads/ 2017/09/vud_gos_budg_II_kv_2014_2017.pdf(in Ukrainian)

Pro mobilizatsiiu dodatkovykh koshtiv na finansuvannia sotsialnykh vyplat [On mobilization of additional funds for the financing of social benefits] (Decree of the President of Ukraine of June 18, 1998 no. 654/98). Retrieved from: http://zakon.rada.gov.ua/laws/show/654/98 (in Ukrainian)

Bekerskaia, D. A. (1973). Pravovoe rehulirovanie spetsialnykh (vnebiudzhetnykh) sredstv biudzhetnykh uchrezhdenii [Legal regulation of special (extra budgetary) funds of budgetary institutions]. Odessa. (in Russian)

Biudzhetnyi kodeks Ukrainy [The Budget Code of Ukraine] (no. 2542-III of June 21, 2001). Vidomosti Verkhovnoi Rady Ukrainy, 37-38, 189. (in Ukrainian)

Biudzhetnyi kodeks Ukrainy [The Budget Code of Ukraine] (No. 2456-VI of June 21, 2001). Vidomosti Verkhovnoi Rady Ukrainy, 50-51, 572. (in Ukrainian)

Chubenko, A. H. (2012). Teoretyko-pravovi zasady finansuvannia systemy tsyvilnoho zakhystu [Theoretical and legal bases of financing of the system of civil protection]. Dissertation of Doctor of Judicial Sciences in specialty 12.00.07. Natsionalna akademiia vnutrishnikh sprav. Kyiv. (in Ukrainian)

Pro tsentralni orhany vykonavchoi vlady [On central executive bodies] (Law of Ukraine no. 3166-VI of March 17, 2011). Vidomosti Verkhovnoi Rady Ukrainy, 38, 385. (in Ukrainian)

Pro Antymonopolnyi komitet Ukrainy [On the Antimonopoly Committee of Ukraine] (Law of Ukraine no. 3659-XII of November 26, 1993). Vidomosti Verkhovnoi Rady Ukrainy, 50, Art. 472. (in Ukrainian)

Pro Natsionalnu politsiiu [On National Police] (Law of Ukraine no. 580-VIII of July 2, 2015). Vidomosti Verkhovnoi Rady Ukrainy, 40-41, Art. 379. (in Ukrainian)

Pro okhoronnu diialnist [On protective activities] (Law of Ukraine no. 4616-VI of March 22, 2012). Vidomosti Verkhovnoi Rady Ukrainy, 2, Art. 8. (in Ukrainian)

Zavalnyi, M. V. (2018). Administratyvno-pravovi zasady diialnosti ta vzaiemodii derzhavnykh ta nederzhavnykh subiektiv pravo okhorony v Ukraini [Administrative and legal principles of activity and interaction of public and non-public subjects of the law protection in Ukraine]. Dissertation Abstract of Doctor of Juridical Sciences in specialty 12.00.07. Kharkiv National University of Internal Affairs. Kharkiv. (in Ukrainian)

Bulycheva, N. A. (2004). Pravovi zasady pozabiudzhetnoi diialnosti orhaniv vnutrishnikh sprav [Legal principles of extra budgetary activity of the law-enforcement bodies]. Dissertation of $\mathrm{PhD}$ in specialty 12.00.07. K. (in Ukrainian) 